\title{
Pathways that Converge in Teacher Professional Development: Are they present in Spain?
}

\author{
Elena MARTÍN
}

Universidad Autónoma de Madrid (Spain)

(Received on May 24, 2015; Accepted on August 2, 2015)

\begin{abstract}
The aim of this article is twofold. First, we present an analysis of the main features of the teacher professional development (PD) models and programs currently considered of highest quality. This analysis is supported by the articles presented in the present monograph, and it also considers other studies that complement these perspectives. We show that axes of teacher change deal with career-long development, reflection in school-based communities of practice, and focus on students' voices. In addition, we highlight the need for coherence between teacher policies and more global policies aimed at enhancing the quality of education. The second objective is to assess the situation of teacher PD within the Spanish education system, using the identified axes of teacher change as an analytic framework. The comparison reveals important limitations from the points of view of both the specific PD activities offered to teachers and underlying teacher PD model.
\end{abstract}

Keywords: teacher professional development, collaboration among teachers, learning communities, reflective practice

Correspondence: Elena Martín Ortega. Full Professor. Facultad de Psicología. Universidad Autónoma de Madrid. 28049 Madrid. Phone: (+34) 914975176. E-mail: elena.martin@uam.es

\section{How to cite this article?}

Martín, E. (2015). Pathways that converge in teacher professional development: Are they present in Spain? (trans. into English by A. Bautista \& J. Wong). Psychology, Society and Education, 7(3), 327-342. [O.V.: Caminos se consolidan en el desarrollo profesional docente. ¿Están presentes en España?, Psicología, Sociedad y Educación, 7(3), 442-458]. 


\section{Introduction}

Nowadays, there is wide agreement among educational scholars and policymakers about the importance of teachers in the enhancement of the quality of education (European Commission/EACEA/Eurydice, 2013; MacBeath, 2012; Mourshed, Chijioke \& Barber, 2010; UNESCO-OREALC, 2014). Unfortunately, such conviction is not always translated into coherent educational policies. It is not difficult to identify a series of widely accepted theoretical assumptions about teacher learning and change. These assumptions can be identified in certain education systems that stand out because of their commitment to educational innovation (Avalos, 2011; Borko, 2004; Vaillant \& Marcelo, 2015; Stigler \& Hiebert, 2009; Villegas-Reimers, 2003).

In the five articles included in this monograph, experts in the field of teacher professional development (PD) analyze the $\mathrm{PD}$ experiences in their respective countries (Australia, Finland, Hong Kong, United States of America, and Singapore). The articles show that PD practices promoted by educational administrations in these countries have important similarities. In the first part of this paper, we present the axes that in our opinion are most essential for the advancement of teacher PD models. These axes can be identified to a great extent in the five countries featured. In the second part, we analyze the reality of the Spanish educational system on the basis of these axes.

\section{From knowledge updating to professional development}

The first change refers to the very concept of teacher PD. The conception of a process focused on knowledge updating has given way to another that is focused on offering teachers the conditions to develop themselves in all the varied and complex dimensions of their professional life. This change requires teachers to restructure their own conceptions, values, attitudes, and of course practices. This is a dynamic and unending process that requires time and must be present throughout teachers' professional careers. Ultimately, this change requires rethinking what being a teacher means today.

The global, permanent, and substantive nature of this transformation is reflected in the five prior articles, but perhaps the expression that best describes this transformation is the one used by Ling and Mackenzie (2015). Following Barnet (2012), these authors qualify the depth of the change as an "ontological turn." It is undeniable that teacher PD is affected by the deep changes of our current information society (Castells, 2000). Take, for example, the developing trend for life-long learning. Life-long learning is an essential need in today's society. Schools now face the challenge of developing students' competency of learning how to learn before the end of compulsory education. Uncertainty is the most distinctive feature of current societies. It is vital for new citizens to face the future with intellectual flexibility, and to know how to control the emotional anxiety provoked by unpredictable situations. Informal learning settings are gaining relevance; schools are no longer the only place where knowledge is acquired. This compels us to rethink the role of school and to resituate its position amongst the different educational settings (Coll, 2013; Ito et al. 
2013). Teaching is now a different task and being a teacher requires redefining the functions of schooling and of those who help students in constructing knowledge.

The profound change occurred in the characterization of teachers' role and in the ways to support their development is not only explained by social transformations, but also by recent shifts in the way that teaching and learning are conceptualized. Cognitive approaches have been enriched with sociocultural perspectives, as shown by Avalos (2011) in her informative literature review. Some of the theoretical constructs that illustrate this evolution are, for example, the influences of culture and society in educational practices, mediation understood as an aid to learner's active constructions, and new technologies as key semiotic tools for learning (Sawyer, 2008; Wells, 1999). Being a teacher has another meaning within a sociocultural conception. It refers to a much more complex professional profile. Based on Scardamalia and Bereiter (2006), teachers are expert professionals who are able to solve open-ended problems, rather than address changes through previously learned routines (Niemi, 2015).

The "Teacher Professional Growth" model proposed more than a decade ago by Clark and Hollingsworth (2002), mentioned in some of the papers of this monograph, accurately reflects this complexity. On one hand, teachers must change with regards to aspects that are related to their self and their professional practice. On the other hand, the model emphasizes the influences of the school and the social context over this change. Achieving such change requires taking all these interconnected factors into consideration. As Ling and Mackenzie (2015) explain, drawing on Opfer and Pedder (2011), teacher learning cannot be understood as an isolated event but as a system with different constructions levels, and therefore, also with different intervention levels. Teacher PD is a dynamic system that evolves across time, and requires planning and supporting the development of teachers during the two-three decades that span their professional careers.

\section{Reflection and self-regulation: keys to professional development}

The complexity of teaching requires autonomous professionals who analyze and understand the contextual demands, plan their behaviors intentionally, and revise them periodically and systematically, modifying them based on the results obtained and on the social changes that influence the function of school. Teaching in this approach involves having sophisticated capacities for reflection and self-regulation. More than three decades ago, Schön $(1983,1987)$ attacked technical rationality, which conceptualized teachers as mere executors of what others asked them to do. Back then, Schön's position was still marginal. Although most scholars in the academic community currently conceive of teachers as reflective professionals, this conception is still not widespread in school practical settings.

This approach has important consequences for the design of teacher PD. The first one relates to the conception of learning on which PD is based, specifically regarding the relationships between cognition and action. Teacher PD is a process that originates in reflection about practice. Having access to new information does not produce this process. Certainly, PD involves the construction of new knowledge. 
However, this knowledge is generated by making explicit the ideas and beliefs teachers have and by contrasting and re-elaborating them based on direct experience within the classroom. PD activities must therefore involve the analysis of the events that occur in class, providing these events with new meanings, revisiting the different aspects involved in teaching, and revising their effect on the learning of students: a recursive cycle of reflection about practice (Postholm, 2008; Pozo et al. 2010; Thorsen \& DeVore, 2013; Zeichner \& Liston; 1996). Short courses and workshops that are unrelated to the everyday activities and tasks teachers do may be useful to create awareness or to acquire new information but, in this perspective, will not result in durable professional development changes.

In order to support the processes of reflection and change, we need to pay attention to the emotions experienced by the teachers. Facing the uncertainties associated with change, within a landscape as demanding and unpredictable as the one described above, generates anxiety. Thus, it is not all about cognitive resistance Educating a teacher requires having an expert professional guiding the teacher along the process, anticipating difficulties and planning the necessary aids, by making explicit the teacher's feelings and normalizing them (Martín \& Cervi, 2006; Zembylas, 2010).

Being anchored in practice as the origin of teacher learning implies considering the importance of contextual factors and the specificities of knowledge domains. Processes of knowledge explicitation and restructuring are neither content-free nor indifferent to contextual influences, but situated and specific to a given subject matter (Avalos, 2011). This does not mean that generalization is impossible, but that generalization is neither simple nor automatic. Professional knowledge encompasses competencies that are common to different teaching situations, as well as competencies that are specific to the learning of particular content areas. However, the former cannot be constructed "in the vacuum" (i.e., without a specific content). Professional knowledge must be constructed based on situations contextualized in practical teaching settings (Clarke \& Hollingsworth, 2002; Nielsen, Barry, \& Staab, 2008; Wang, Kim, Lee, \& Kim, 2014).

The perspective of reflection about teaching practices is much more demanding for educational administrations. To be successful, it requires certain features in both the school culture and teacher's working conditions. It is vital for teachers to have white spaces to plan and revise their lessons. Teachers should also be able to share these times with other fellow colleagues. Expecting that all teachers will voluntarily spend hours of their time on this difficult task is not realistic, especially if they have to do so outside working hours. Teaching is just one of the many tasks for teachers. Hence, educational innovations that overlook the high workload that may entail for teachers are headed towards failure. As planning, reading, thinking, and re-thinking are activities absolutely essential to teacher PD, these activities must therefore be scheduled within regular school working hours.

Writing facilitates processes of reflection and knowledge explicitation (Klein, Boscolo, Gelati, \& Kirckpatrick, 2014; Scardamalia \& Bereiter, 2006). It is crucial for schools to cultivate the culture of making decisions explicit in written documents. 
Yet schools should try to avoid the situation whereby writing becomes merely a bureaucratic task for teachers. Writing helps us to think, allows us to share projects, and facilitates revision processes. School leaders and those in leadership positions must drive the completion of written documents, as well as their discussion and evaluation.

The role of school leaders is crucial in the design of school-based PD opportunities (Harris, 2008; OECD, 2009). However, teachers must also take responsibility of their own training. Teachers need to feel committed to their own personal project. Indeed, the teacher should be the one regulating her/his own professional career, although the needs of the school should not be negated in a teacher's plan. Similar to many other aspects of development, progress occurs when we move from hetero-regulation to self-regulation. School leaders must help teachers to elaborate their own plans and periodically discuss their achievements. This support and external control have the potential to help teachers, although the teachers' drive must come from within.

However, developing teacher reflection and self-regulation clashes with an expectation that educational administrations commonly have, namely expecting that all teachers should implement similar teaching practices in the classroom. Unfortunately, it is quite common for educational administrators to try to generalize the desired innovations without allowing sufficient time for teachers to internalize such innovations. The tension among autonomy, promptness, and homogeneity in promoting teacher change is one of the most important problems affecting teacher PD. The perverse effect of certain forms of external assessment is the best example of this risk (Darling-Hammond, 2012). As pointed out by Avalos (2011), "In the quest for higher examination scores, they are provided with "outside experts" to teach them how to produce results in the short periods of time demanded by their education systems" (p.18). The pressures that teachers in some educational systems experience as a result of the high student achievement expectations also produce this lack of autonomy. The articles describing PD in Hong Kong (Lam, 2015) and Singapore (Bautista, Wong, \& Gopinathan, 2015) address this issue within the present monograph. In contrast, Finland has adopted an approach of autonomy and local responsibility, in which the goal is for teachers to use the assessment tools and methods that best fit the needs of students. The task of supervision has shifted from control to support and mentorship (Niemi, 2015).

\section{From the teacher to school faculty}

We know that learning processes are fostered when different minds cooperate, for reasons that are both cognitive and emotional (Johnson, Johnson, \& Holubec, 2008, Salomon, 1993). Thinking together facilitates one's awareness of ideas and promotes perspectivism and argumentation. It helps in developing the regulation of our own behavior and that of others, as well as in developing attitudes of respect and appreciation of diversity.

These mechanisms that operate in students are equally valid when it comes to adult learning, including teachers. For teachers, however, there are other reasons that 
make structures for participation especially valuable. To a large extent, teaching quality depends on the coherence among the decisions made by the different teachers who educate the same students. The key is not in the isolated actions of the individual teacher, but instead in the strength of the experiences that recur throughout schooling, as these experiences respond to principles that are shared within the faculty. The goal is not to seek homogeneity but rather coherence. In this way, the school faculty becomes the most powerful unit in fostering teacher PD. Those who share the same educational spaces (teachers who teach the same grade levels, the same subject matters, teachers in charge of specific programs...) are able to jointly analyze common situations, plan changes that involve fellow colleagues, and provide mutual support along the process. These policies are currently being implemented in Australia, Finland, Hong Kong, and Singapore.

For these reasons, even though professional communities do not have to be restricted to the members of the same educational institution, models of teacher PD that take the school as the main intervention unit present many of the features discussed thus far. Apart from these features, it is worth noting the importance of connecting teacher PD with the enhancement of educational quality. This approach makes it easier to identify the training needs of the teachers, within the frame of the school's needs, and help teachers use the new competences acquired to implement plans intended to improve the school. As pointed out by Darling-Hammond and McLaughlin (2003), there are many opportunities for this type of learning and reflective practices in the frame of the tasks carried out every day at school. These authors argue that all the events that occur in schools provide opportunities to foster teacher PD.

When this approach is adopted, the role of school leaders is clearer and more relevant with regards to the support that leaders can offer to teachers and the followup of teachers' plans. Indeed, the role of mentors becomes central in this approach. By assuming the distributed leadership role, a characteristic of innovation experiences, the presence of mentors has potential to foster reflection processes, help teachers to focus on relevant topics, and offer alternative practices (Hobson, Ashby, Malderez, \& Tomlinson, 2009).

Over the past years, experiences in communities of practice have been enriched by incorporating the perspectives of students. Although "Lesson Study" has gained importance as a form of PD, research about its effects is still not entirely conclusive (Hart, Alston, \& Murata, 2011). Teachers are generally satisfied with their Lesson Study experiences, although these are generally costly and require a great deal of resources and support by school leaders (time, material resources, the guidance of a specialist (Lim, Lee, Saito, \& Hairon, 2011). Similarly, the "epistemic communities" inspired on Scardamalia and Bereiter's $(1994,2006)$ approach of "knowledge building community school" have proven to be a promising avenue towards teacher PD (Wang, Kim, Wen, Lee, \& Kim, 2014). Both types of PD experiences are interesting and should therefore be promoted by educational administrations.

In these types of PD experiences, on top of the strength of reflection about action, we need to add the strength of observing another teacher as well as the value 
of the perspective of students. Communities of practice generally entail peer-revision of classroom practices. The relevance and usefulness of the suggestions that other teachers make, based on the observation of classroom practices, have the added value of being contextualized and situated in practical settings. The voices of students bring a perspective that other teachers can hardly offer; this perspective is not necessarily more valuable, but by all means complementary. Attending to the voice of students is a key element of inclusive education (Booth \& Ainscow, 2011; Messiou et al., in press). The "learning communities" approach enriches the comparison of perspectives and knowledge with the presence of other adults from the community (INCLUD-ED Consortium, 2011).

Despite the power of school-based teacher PD, communities of practice often bring together professionals from different educational institutions. Seminars or permanent working groups sharing the same curricular area or teaching project, teams elaborating curriculum materials, or teachers participating with universities in research projects are all partnerships with high potential to foster teacher PD, which therefore may enrich the internal perspectives of schools (Darling-Hamond \& McLaughing, 2003). School networks and networks among different types of institutions also allow for an exchange of experiences. The Collaborative Lesson Planning, organized by the Hong Kong's Education Bureau, is an example of these types of programs. We understand that one of the goals of teacher PD policies is for teachers' growth to positively benefit the school as a whole; that is, finding a balance between the wealth and variety of learning formats and the key role of having spaces to reflect with other colleagues who share the same practice.

\section{Teacher policies in the frame of educational improvement}

The quality of in-service teacher education has always been affected by other teacher policies. This dependency is much more obvious if we adopt an approach that conceptualizes PD as an evolution throughout the processes of construction of identify and teaching competencies. Initial teacher preparation programs should include explicit reflection about what being a teacher means and the importance of collaborative reflection. The need for an induction period responds to these same principles. Induction constitutes a paradigmatic example of the blurred limits between initial and on-going preparation. Furthermore, other aspects with direct implications on teacher PD are the decisions regarding teachers' evaluation (with its function being merely formative or with future implications for the career), the role of school leaders, as well as accreditation standards (Darling-Hammond, 2012). One of the keys for the success of PD is therefore ensuring the coherence with more global teacher policies, which requires making explicit the PD model that has been adopted (Villegas-Reimers, 2003).

It is important to consider, however, that such coherence must go beyond the scope of teachers. Other decisions related to the structure and function of the educational system also have clear influences over the viability of implementing a certain model of teacher PD. There is no doubt that curriculum design is one of these decisions. What conception of learning is being transmitted? Teaching cannot be 
organized independently from what society wants students to learn, or from how learning and knowledge are conceived. There is a direct relationship between teaching competences and school curriculum. For these reasons, it is also necessary to carefully revise the options available to externally assess students' learning and achievement, as pointed out above.

The decisions that influence the culture and organization of schools are equally important. Moving away from the bureaucratic style (OECD, 2009), is the distributed leadership style promoted by educational reforms and policies? Are there times and structures that allow teachers to get together with other fellow colleagues at schools? Are teachers' competencies taken into consideration when the distribution of their responsibilities is planned? Are mentorship programs encouraged? Are students' voices heard? These indicators, which characterize the extent to which schools have innovative cultures, are partially dependent on the internal management of schools. However, these indicators ultimately respond to the decisions taken in educational policies, which allow or not allow the necessary conditions for high-quality education.

This does not mean that schools should restrict themselves to using their own resources. In many countries, universities and educational research centers are very active with regards to teacher PD, as illustrated in the articles of this monograph. The support is given within the frame of partnerships between universities and schools, by seeking the collaboration of teachers in research teams, which ultimately enhances academic knowledge. There are also many examples of contributions to PD by private institutions. Networks in private centers generally have their own training departments. Initiatives of pedagogical innovation also play an important role in this supply. However, if career-long training is understood to be both a right and an obligation for teachers, it would be essential for educational policies to guarantee this training.

Finally, we also consider that administrations should be responsible for assessing the impact of PD policies, whilst drawing on the expertise of researchers. Available evidence is still inconclusive. First and foremost, we need to acknowledge the difficulties in establishing meaningful conclusions from studies whose objective and methodologies are different. This is why results cannot be considered conclusive, as pointed out by Bautista et al. (2015) and Ling and Mackenzie (2015). Some researchers have argued that there are no studies showing that PD is effective (e.g., Darling-Hammond, 2010; Hoekstra \& Korthagen, 2011). However, other reviews do indicate that when PD programs present the features discussed here (reflection on practice, long duration, collaboration with other fellow colleagues within practical settings), changes in the instructional practices of participating teachers can be observed (Avalos, 2011; Hagger, McIntyre, \& Wilkin, 2013; McKernan \& McKernan, 2013, Villegas-Reimers, 2003).

It is even more difficult to assess whether teacher PD programs enhance the learning of students. There are few studies available. However, it is necessary to monitor this dimension of impact by focusing on the learning of specific domains (Bautista et al., 2015; Bautista, Cañadas, Brizuela, \& Schliemann, 2015; Kazemi \& 
Hubbard, 2008). Although the wide diversity of school contexts makes the generalization of results difficult, it is necessary to find in the educational field -as has been done in other fields- common elements that provide a better understanding about the impact of PD on teaching practices. Teaching and learning processes are interactive (Coll, Onrubia, \& Mauri, 2008; Sánchez, García, Rosales, De Sixte, \& Castellano, 2008). Thus, student learning and achievement cannot be exclusively explained by what the teacher does. The capacity of the teacher to adjust herself/himself to the characteristics of students and of the subject matter is key in teaching. The analysis of the relationship between teachers' classroom practices and students' learning is one of the lines of work in which educational research still has a lot to offer.

\section{Teacher professional development in Spain}

When we analyze the situation of teacher PD within the educational system in Spain, using the lenses of the tenets discussed here, the landscape is not positive. In 1984, Spain adopted the English "Teacher's Center" model in the experimental reform that gave rise to the most influential educational law since the democratic transition (LOGSE, 1990). This decision brought about the decentralization of teacher training, as well as an important increase in the number of educational consultant teams focusing on on-going teacher training. Spain implemented a cascading training strategy: experts trained other professionals, who in turn organized courses and training activities for all teachers. Additionally, the LOGSE educational law established salary rises associated to on-going teacher training, which is still in place in most Autonomous Communities today. If teachers complete 100 hours of training in a period of six years, they receive a pay rise of about $4.5 \%$.

As pointed out by Imbernón (2014), this period of strong commitment to continuing education was taken over by autonomic governments until before year 2000, when all the competences in education matters were transferred to the 17 communities. With some small differences, the original model was maintained in most cases. However, during the three past decades, a weakening of the structures for continuing teacher education has occurred. Only six communities have maintained the networks of teacher centers. In the rest, these have been eliminated, leaving only one reference center in each province or an analogous administrative unit, with the corresponding decrease in the number of PD opportunities available. The educational administrators generally argue that this lack of support is due to Spain's current crisis. However, it is also important to consider that politics in Spain have been clearly conservative during the past years, especially when it comes to education. Most private institutions have their own resources to train their own teachers. Yet supporting public schools is no longer among the priorities for conservative governments, who currently govern both the state administration and many autonomous communities.

Additionally, it is important to highlight that even during times when PD received most support, the model of continuing teacher education was based on the delivery of courses for teachers to upgrade their knowledge. School-based PD 
activities, seminars, and team group work are rather infrequent, even though some administrations are trying to foster these types of initiatives (Manzanares \& Galván Bovaira, 2012; OECD, 2009). Professional learning communities such as the ones described in this monograph (where teachers engage in activities like lesson study, action-research, co-tutoring) have a very small presence in the Spanish educational landscape. Similarly, the Movements of Pedagogical Innovation are associations that played an essential role in school innovation and teacher PD. However, these associations have experienced a substantial deterioration due to the lack of support provided by administrations.

As is usually the case, this precarious situation is not limited to teacher continuing education but it also characterizes the whole set of teacher policies. In the 2009-2010 academic year, the university qualifications required to teach in Childhood Education and Primary Education advanced from a 3-year diploma to a 4year degree. However, unlike countries such as Finland and Singapore, candidates accepted in teacher education programs are not those who obtained the highest academic achievement. Moreover, in order to teach in Secondary schools, graduates only needed to obtain the "Certificate of Pedagogical Aptitude," which was unanimously considered poor in quality. From 2009, graduates in the different disciplines must complete a 1-year master's degree, which is a significant improvement. This master's degree, however, still does not provide an appropriate response to the complex profile of competences that teachers at these educational levels need (Manso \& Martín, 2013). As shown by Escudero (2009) in a very interesting comparison between the Teaching Competencies General Framework elaborated by the Hong Kong government in 2008 and the Master of Teaching in Spain, the Spanish model continues to be too focused on the disciplines themselves.

With regards to induction, the exam that grants access to the teaching profession in Spanish public schools is still too "memoristic" in nature. Additionally, experts in education have been arguing for a period of induction when teachers join the teaching profession (Marcelo, 2009). Despite the high number of teachers who support the implementation of this induction period (Valle \& Manso, 2014), this period has not yet been established, although there are initial debates discussing the possibility of adopting a residency model similar to the one used with novice medical doctors (Marchesi \& Martín, 2014).

Agreements regarding the teaching career among the different administrations or with teacher unions have not been reached either. Spain has neither a nation-wide nor autonomic systems for the assessment or the accreditation of its teachers. In the Spanish educational system, attempts to standardize the evaluation of teachers' work have been rare. This lack of systematic evaluation procedures has important implications, as teachers cannot use their evaluations with a formative purpose or to guide their teaching careers. The situation of Spain regarding this aspect of teacher policies reveals a clear stagnation as compared to the international landscape (OECD, 2009).

Teachers generally join the teaching profession with a reasonable salary, somewhat lower in private schools, and retire 30 years later achieving no 
improvement in their working conditions (OECD, 2010) and with no avenues to pursue their own professional development. Schools have little autonomy in Spain and the role of school administrations in the regulation of staff is practically nonexistent (Pont, Nusche, \& Moorman, 2008). Lately, universities continue to be disconnected from teachers' continuing education (with the exception of a few valuable cases), and do not promote school teachers' participation in research projects.

Perhaps this is contributing, alongside many other factors, to a general feeling of discomfort among teachers, and also to perpetuating the belief among teachers that their job is not as highly valued as it really should be. Several studies have showed clear differences between the recognition that society gives to teachers and the recognition that teachers themselves attribute to their profession (Fundación BBVA, 2009; Fundación Europea Sociedad y Educación, 2013, Marcelo, 2011; OECD, 2009). Societal recognition is slightly higher than the recognition teachers think they have, but lower than the recognition they would like to obtain, which is in fact very similar to what occurs with other liberal professions. As pointed out by Enguita (2009; Fernandez Enguita \& Riviére Gómez, 2010), this pessimistic view is one of the distinctive characteristics of the teaching profession in Spain.

The fact that the general landscape in Spain is not stimulating does not negate the existence of certain interesting initiatives, in which the features discussed in this article can be identified. Fortunately, there are valuable examples (some of them have been cited above) that show how certain teachers have been able to confront "fossil" policies, as coined by Darling-Hammond and McLaughlin (2003). It is encouraging to observe how those innovations implemented by the pioneer schools of the Spanish reform respond to the general guidelines for the improvement of quality teaching and learning that have been analyzed in the beginning of this article (INCLUDE-ED, 2011; Ministerio de Educación, 2011; Mourshed et al., 2010). ${ }^{i}$ The difference with respect to other countries, including the ones featured in this monograph, is that these success stories in Spain are still rather rare, not representing the general tendency.

The situation of the Spanish educational system clearly illustrates how cultural and systemic dimensions of change require moving from a model of knowledge updating to a professional development model. The ideas that make this change possible have been known for a long time and are accepted from a theoretical standpoint (see the monograph on teaching published by Revista de Education; see AA.VV., 2006). Academics in Spain also consider that the goal is for teachers to grow as professionals through collaborative reflection about practice. However, this model has not been clearly translated into the general education policies, and it has therefore not reached the majority of schools. The change we have discussed here is not dependent on isolated teachers; key features like the school culture, and ultimately a supportive school system have to be put in place. In those countries that have progressed in this direction, change has been slow. Ideas have always preceded practices. Minority avant-gardes implemented new ideas first, as it generally occurs. Educational policymakers adopted these ideas at a later point in time, translating them into conditions for change. On-going firm and sustained support by educational 
administrations is not enough for promoting the cultural transformation that this teacher PD model requires, although with no support, it will be impossible to make progress in this crucial aspect of educational quality.

The Spanish Ministry of Education and the leaders of the autonomic administrations should consider the solid evidence presented in this monograph. Teacher policies should become a budgetary priority in education. Increasing the budget invested in teachers is vital to ensure the success of the measures that have been described (reducing teachers' teaching hours in order for them to participate in professional faculty meetings; reducing mentors' teaching hours; establishing different levels of professional career; offering high-quality PD initiatives; collaborating with research projects run by universities). In order to improve its education system, Spain needs to increase monetary resources and agree on normative frameworks that regulate the teaching statutes and the training of beginning teachers.

\section{References}

AA.VV. (2006). La tarea de enseñar: atraer, formar, retener y desarrollar buen profesorado. Revista de Educación. Monográfico, 340.

Avalos, B. (2011). Teacher professional development in Teaching and Teacher Education over ten years. Teaching and Teacher Education, 27(1), 10-20.

Barnett, R. (2012). Learning for an unknown future, Higher Education Research \& Development, 31(1), 65-77.

Bautista, A. Wong, J., \& Gopinathan, S. (2015). Teacher professional development in Singapore: Depicting the landscape. Psicología, Sociedad y Educación, 7(3), 311-326.

Bautista, A., Cañadas, M. C., Brizuela, M. B., \& Schliemann, A. D. (2015). Examining how teachers use graphs to teach mathematics in a professional development program. Journal of Education and Training Studies, 3(2), 91106. doi: 10.11114 jets.v3i2.676

Booth, T. \& Ainscow, M. (2011). Index for inclusion: developing learning and participation in schools ( $3^{\text {rd }}$ edition). Bristol: Centre for Estudies in Inclusive Education (CSIE).

Borko, H. (2004). Professional development and teacher learning: Mapping the terrain. Educational Researcher, 33(8), 3-15. http://dx.doi.org/10.3102/0013189X033008003

Castells, M. (2000). La era de la información. Vol. 1. La sociedad red. Madrid. Alianza.

Clarke, D., \& Hollingsworth, H. (2002). Elaborating a model of teacher professional growth. Teaching and Teacher Education, 18, 947-967.

Coll, C. (2013). El currículo escolar en el marco de la nueva ecología del aprendizaje. Aula, 219, 31-36.

Coll, C., Onrubia, J. \& Mauri, T. (2008). Ayudar a aprender en contextos educativos: el ejercicio de la influencia educativa y el análisis de la enseñanza. Revista de Educación, 346, 33-70.

Darling-Hammond, L. (2010). Teacher Education and the American Future. Journal of Teacher Education, 61(1-2), 35-47. http://dx.doi.org/10.1177/0022487109348024

Darling-Hammond, L. (2012). Evaluating and supporting effective teaching: Developing a systemic approach. Pensamiento Educativo, 49(2), $1-20$ doi:10.7764/PEL.49.2.2012.1 
Darling-Hammond, L. \& McLaughlin, M.W. (2003). El desarrollo profesional de los maestros. Nuevas estrategias y políticas de apoyo. México, D.F.: Secretaría de Educación Pública.

Escudero, J. M. (2009). La formación del profesorado de Educación Secundaria: contenidos y aprendizajes docentes. Revista de Educación, 350, 79-103.

European Commission/EACEA/Eurydice (2013). Key Data on Teachers and School Leaders in Europe. 2013 Edition. Eurydice Report. Luxembourg: Publications Office of the European Union.

Fernández Enguita, M. (2006). Pero... ¿qué querrán? El estatus del profesorado y el tópico del reconocimiento. Cuadernos de Pedagogía, 353, 80-85.

Fernández Enguita, M. \& Rivière Gómez, J. (Eds.) (2010). Barómetro del Profesorado. Escuela, 3.869, 3 de junio de 2010 (suplemento especial).

Fundación BBVA (2009). Participación política y social y confianza en grupos profesionales e instituciones. Recuperado el 17 de enero de 2015 en http://www.fbbva.es/TLFU/tlfu/esp/investigacion/fichainves/index.jsp?codigo=369

Fundación Europea Sociedad y Educación (Eds.) (2014). El prestigio de la profesión docente en España: percepción y realidad. Madrid: Fundación Europea Sociedad y Educación. Recuperado el 28 de febrero de 2014 en http://www.sociedadyeducacion.org/publicaciones/coleccion-propia/

Hagger, H., McIntyre, D., \& Wilkin, M. (Eds.) (2013). Mentoring: perspectives on schoolbased teacher education. London: Routledge.

Harris, A. (2008). Distributed leadership in schools: Developing the leaders of tomorrow. London: Routledge \& Falmer Press.

Hart, L. C., Alston, A., \& Murate, A. (Eds.) (2011). Lesson study research and practice in mathematics education: Learning together. Dordrecht, The Netherlands: Springer.

Hobson, A. J., Ashby, P., Malderez, A., \& Tomlinson, P. D. (2009). Mentoring beginning teachers: what we know and what we don't. Teaching and Teacher Education, 25(1), 207-216.

Hoekstra, A., \& Korthagen, F. (2011). Teacher learning in a context of educational change: Informal learning versus systematically supported learning. Journal of Teacher Education, 62(1), 76-92. http://dx.doi.org/10.1177/0022487110382917

http://www.fbbva.es/TLFU/tlfu/esp/investigacion/fichainves/index.jsp?codigo=369

INCLUDE-ED Consortium (2011). Actuaciones de éxito en las escuelas europeas. Madrid: Ministerio de Educación. Recuperado el 87 de diciembre de 2014 en http://www.nesetweb.eu/sites/default/files/actuaciones-de-exito-en-las-escuelaseuropeas.pdf

Imbernon, F. (2014). La formación permanente 40 años después: de la ilusión a los recortes. Cuadernos de Pedagogía, 451, 56-59.

Ito, M., Gutiérrez, K., Livingstone, S., Penuel, B., Rhodes, J., Salen, K., Schor, J., SeftonGreen, J. \& Watkins, S. C. (2013). Connected Learning: An Agenda for Research and Design. Irvine, CA: Digital Media and Learning Research Hub.

Johnson, D. W., Johnson, R. \& Holubec, E. (2008). Cooperation in the classroom. Edina, $\mathrm{MN}$ : Interaction Book Company.

Kazemi, E., \& Hubbard, A. (2008). New directions for the design and study of Professional Development. Attending to the coevolution of teachers' participation across contexts. Journal of Teacher Education, 59(5), 428-441. 
Klein, P., Boscolo, C., Gelati, P., \& Kirckpatrick, L. (Eds.) (2014). Writing as a Learning Activity. Leiden, Netherlands: Koninklijke Brill.

Lam, B. H. (2015). Teacher Professional Development in Hong Kong Compared to Anglosphere: the Role of Confucian Philosophy. Psicología, Sociedad y Educación, 7(3), 295-310.

Lim, C., Lee, C., Saito, E., \& Hairon, S. (2011). Taking stock of Lesson Study as a platform for teacher development in Singapore. Asia-Pacific Journal of Teacher Education, 39(4), 353-365. doi: 10.1080/1359866X.2011.614683

Ling, L. M. \& Mackenzie, N. M. (2015). An Australian perspective on teacher professional development in supercomplex times. Psicología, Sociedad y Educación, 7(3), 264-278.

MacBeath, J. (2012). Future of teaching profession. Cambridge: University of Cambridge and Educational International Research Institute.

Manso, J. \& Martín, E. (2014). Valoración del Máster de formación de profesorado de Educación Secundaria: Estudio de casos en dos universidades. Revista de Educación, 364, 145-169.

Manzanares, A. \& Galván-Bovaira, A. (2012). La formación permanente del profesorado de educación infantil y primaria a través de los centros de profesores. Un modelo de evaluación. Revista de Educación, 359, 431-455 DOI: 10-4438/1988-592X-RE-2010359-101.

Marcelo, C. (2009). Profesorado principiante e inserción profesional a la enseñanza. Barcelona: Octaedro.

Marcelo, C. (2011). La profesión docente en momentos de cambios. ¿Qué nos dicen los estudios internacionales? CEE Participación Educativa, 16, 49-68.

Marchesi, A. \& Martín, E. (2014). Calidad de la enseñanza en tiempos de crisis. Madrid: Alianza.

Martín, E. y Cervi. J. (2006). Modelos de formación docente para el cambio de concepciones en los profesores. En Nuevas formas de pensar el aprendizaje y la enseñanza. Concepciones de profesores y alumnos (pp. 420-434). Barcelona: Graó.

McKernan, J., \& McKernan, J. (2013). Curriculum action research: A handbook of methods and resources for the reflective practitioner (2nd Ed.). London: Routledge.

Messiou, K., Ainscow, M., Echeita, G., Goldrick, S., Hope, M., Paes, I., Sandoval, M., Simon, C. \& Vitorino, T. (in press). Learning from differences: a strategy for teacher development in respect to student diversity. School Effectiveness and School Improvement. doi:10.1080/09243453.2014.966726.

Ministerio de Educación-IFIIE (2011). Estudio sobre la innovación educativa en España. Madrid: Publicaciones del Ministerio de Educación.

Mourshed, M., Chijioke, Ch., \& Barber, M. (2010). How the world's most improved school systems keep getting better. Londres: McKinsey \& Company. Recuperado el 23 de enero del 2012 de http://mckinseyonsociety.com/how-the-worlds-most-improvedschool-systems-keep-getting-better/

Niemi, H. (2015). Teacher professional development in Finland: Towards a more holistic approach. Psicología, Sociedad y Educación, 7(3), 279-294.

OCDE (2009). Creating Effective Teaching and Learning Environments: First results from TALIS. París OCDE. Recuperado el 19 de febrero de 2013 en http://www.oecd.org/edu/school/43023606.pdf

OCDE (2010). Education at a Glance. 2010. París: OCDE. Recuperado el 16 de marzo de 20014 en http://www.oecd.org/edu/eag2010 
Opfer, V. \& Pedder, D. (2011). Conceptualizing teacher professional learning. Review of Educational Research, 81(3), 376-407.

Pont, B., Nusche, D., \& Moorman, H. (2008). Improving school leadership. Vol. 1: Practice and policy. Paris: OCDE.

Postholm, M. B. (2008). Teachers developing practice: Reflection as key activity. Teaching and Teacher Education, 24(7), 1717-1728.

Pozo, J. I., Martín, E., Pérez-Echeverría, M. P., Scheuer, N., Mateos, M. \& de La Cruz, M. (2010). Ni contigo ni sin ti... Las relaciones entre cognición y acción en la práctica educativa. Infancia y Aprendizaje, 33(2), 179-184. doi:10.1016/j.tate.2008.02.024

Salomon, G. (1993). No distribution without individuals" cognition: A dynamic interactional view. In Salomon, G. (Ed.), Distributed Cognitions (pp. 111-138). New York: Cambridge University Press.

Sánchez, E., García, J. R., Rosales, J, De Sixte, R \& Castellano, N. (2008). Elementos para analizar la interacción entre estudiantes y profesores: ¿qué ocurre cuando se consideran diferentes dimensiones y diferentes unidades de análisis? Revista de Educación, 346, 105-136.

Sawyer, R. K. (2008). Optimizing learning implications of learning sciences research. In CERI/OECD, Learning in the 21st Century: Research, Innovation and Policy. Paris: OECD Publications.

Scardamalia, M. \& Bereiter, C. (1994). Computer support for knowledge-building communities. The Journal of the Learning Sciences, 3(3), 265-283

Scardamalia, M. \& Bereiter, C. (2006): Knowledge building: Theory, pedagogy and technology. En R. K. Sawyer (Ed.), The Cambridge handbook of the learning sciences (pp. 97-115). New York: Cambridge University Press.

Schön, D. A. (1983). The Reflective Practitioner: How professionals think in action. London: Temple Smith.

Schön, D. A. (1987). Educating the Reflective Practitioner. San Francisco: Jossey-Bass.

Stigler, J. W., \& Hiebert, J. (2009). The teaching gap: Best ideas from the world's teachers for improving education in the classroom. New York, NY: Free Press.

Thorsen, C. A., \& DeVore, S. (2013). Analyzing reflection on / for action: A new approach. Reflective Practice: International and Multidisciplinary Perspectives, 14(1), 88-103. doi:10.1080/14623943.2012.732948

UNESCO-OREALC (2014). Temas críticos para formular nuevas políticas docentes en América Latina y el Caribe: el debate actual. Santiago de Chile: Unesco-Orealc.

Vaillant, D. \& Marcelo, C. (2015). El ABC y D de la formación docente. Madrid: Narcea.

Valle, J. \& Manso, J. (2014). La voz del profesorado: Acceso a la profesión docente e inserción en el puesto de trabajo. Consejo General de los Ilustres Colegios Oficiales de Doctores y Licenciados en Filosofía y Letras y en Ciencias. Recuperado el 7 de noviembre del 2014 en http://www.consejogeneralcdl.es/

Villegas-Reimers, E. (2003). Teacher professional development: an international review of the literature. Paris: International Institute for Educational Planning.

Wang, X., Kim, B. Lee, J \& Kim, M. S. (2014). Encouraging and being encouraged: Development of an epistemic community and teacher professional growth in a Singapore classroom. Teaching and Teacher Education, 44, 12-24.

Wells, G. (1999). Dialogic Inquiry. Cambridge, R.U: The Press Syndicate of the University of Cambridge. 
Zeichner, K. \& Liston, D. (1996). Reflective Teaching: an introduction. Mahwah, New Jersey: Lawrence Erlbaum Associates.

Zembylas, M. (2010). Teacher emotions in the context of educational reform. In A. Hargreaves, A. Lieberman, M. Fullan \& D. Hopkins (Eds.), Second International Handbook of educational change (pp. 221-236). London: Springer.

\footnotetext{
'The initiatives described in the two national journals most widely spread among teachers, Cuadernos de Pedagogía and Aula de Innovación, are good examples of these valuables innovations.
} 